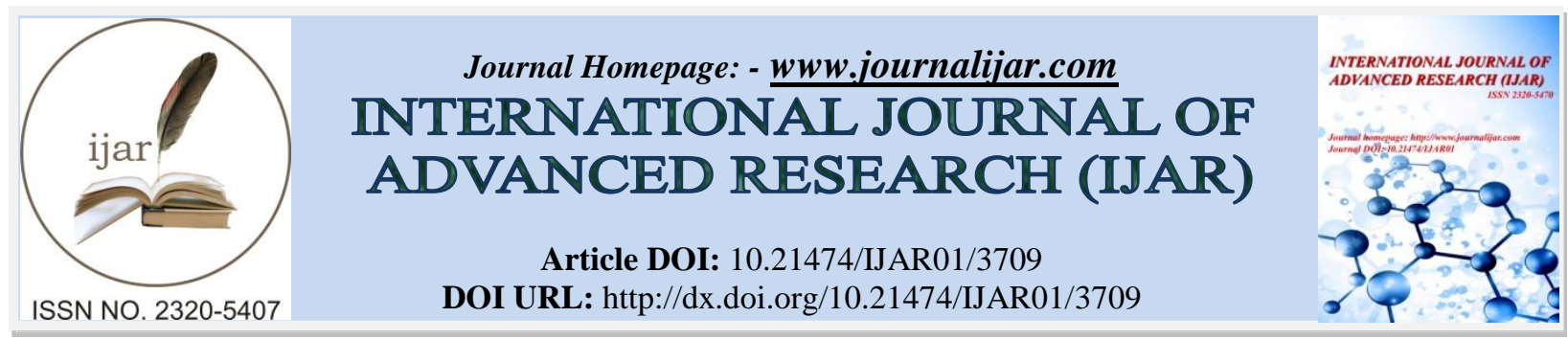

RESEARCH ARTICLE

\title{
A CASE STUDY ON THE EFFECT OF PUNARNAVA (Boerhavia diffusa.Linn) IN GALACTORRHOEA.
}

\begin{abstract}
Khatun Hazera.
Dept of Samhita and Siddhanta. Asst. professor of Raghunath Ayurved Mahavidyalaya and hospital. Contai, PurvaMedinipur.WestBengal.
\end{abstract}

\section{Manuscript Info}

Manuscript History

Received: 15 January 2017

Final Accepted: 04 February 2017

Published: March 2017

Key words:-

Ayurveda, case study, galactorrhoea, hyperprolactenemia, srotodusti.

\begin{abstract}
Galactorrhoea is one of the common complain found in adolescence to post menopausal women. Though it has varied etiology but most common cause is hyperprolactenemia. Long term use of hormonal therapy is the only way of management in modern medical science. This gives scope to find alternative treatment measures to relieve the patient from physical, mental, social discomfort and also harmful effect of long term hormonal therapy.

In Ayurveda, galactorrhoea can be compared to a symptom manifesting due to Rasavaha sroto dusti. Here type of srotodusti is Atipravritti. Stanya(milk) is the upadhatu of rasa dhatu. Galactorrhoea is nothing but Stanyavriddhi. The objective of the treatment includes finding out exact culprit for galactorrhoea and symptomatic relief.

The present study has been conducted on a patient suffering from galactorrhoea for fifteen days which is due to mild elevation of serum prolactine level. The treatment plan includes Langhan in term of dietary restriction, life style modification and capsule Punarnava and capsule Trikatu orally. After ten days galactorrhoea stop and patient was symptomatically fine. The pathogenesis, treatment details, mode of action, result are discussed in detail in full paper.
\end{abstract}

Copy Right, IJAR, 2017,. All rights reserved.

\section{Introduction:-}

Galactorrhoea is a discharge of milk or a milk-like secretion from the breast in the absence of parturition or beyond six months' post-partum in a non breastfeeding woman. The secretion may be intermittent or persistent, scant or abundant, free-flowing or expressible, and unilateral or bilateral. The condition is more common in women who are 20 to 35 years of age and in previously parous women; it is less common in children and nulligravid women. Galactorrhea also can occur in men. In children, galactorrhea is more common in infants and teenage girls. The condition may result in patient anxiety and can signify a serious underlying disorder. Galactorrhea is commonly associated with hyperprolactinemia. [1] Prolactin plays an important role in growth of mammary gland. It causes proliferation of epithelial cell of alveoli thereby inducing and maintaining milk production. Prolactin is responsible for lactogenesis. During pregnancy, particularly in latter months; large quantity of prolactin is secreted. But the activity of this hormone is suppressed by estrogen and progesterone secreted by placenta. Because of this, lactation is prevented during pregnancy. Immediately after the delivery of the baby and expulsion of placenta, there is sudden lisoss of estrogen and progesterone. Now, the prolactin is free to exert its action on breast and to promote lactogenesis.[2]

Corresponding Author:- Khatun Hazera.

Address:- Dept of Samhita and Siddhanta. Asst. professor of Raghunath Ayurved Mahavidyalaya and 
Galactorrhoea itself isn't a disease, but it could be a sign of an underlying problem. This condition occurs in less than $1 \%$ of the general population and in $5-14 \%$ of patients presenting with secondary amenorrhea. Approximately $75 \%$ of patients presenting with galactorrhea and amenorrhea have hyperprolactinemia. Of these patients, approximately $30 \%$ have prolactin-secreting tumors.[3]

Mortality/Morbidity:-

Mortality is unlikely; however, in cases where the condition is due to a large prolactin-secreting tumor, local mass effect can lead to significant morbidity. [4]

Causes of Galactorrhoea:-[5]

Some Medications Associated with Galactorrhea:-

Dopamine-receptor blocker:- Butyrophenones, Metoclopramide (Reglan), Phenothiazines, Risperidione (Risperdal).

Selective serotonin reuptake inhibitor:- Sulpiride, Thioxanthenes, Tricyclicantidepressants.

Dopamine-depleting agents:- Methyldopa (Aldomet), Reserpine (Serpasil).

Inhibition of dopamine release:- Codeine, Heroin, Morphine.

Histamine-receptor blocker:- Cimetidine (Tagmet) etc.

Other causes of galactorrhea include:-

Herbal supplements, such as fennel, anise or fenugreek seed, Birth control pills, Noncancerous pituitary tumor (prolactinoma) or other disorder of the pituitary gland, Underactive thyroid (hypothyroidism), Chronic kidney disease, Excessive breast stimulation, which may be associated with sexual activity, frequent breast self-exams with nipple manipulation or prolonged clothing friction, Nerve damage to the chest wall from chest surgery, burns or other chest injuries, Spinal cord surgery, injury or tumors

\section{Idiopathic galactorrhoea:-}

Sometimes doctors can't find a cause for galactorrhoea. This is called idiopathic galactorrhoea, and it may just mean that your breast tissue is particularly sensitive to the milk-producing hormone prolactin in blood.

\section{Galactorrhoea in Men:-}

In males, galactorrhoea may be associated with testosterone deficiency (male hypogonadism) and usually occurs with breast enlargement or tenderness (gynecomastia). Erectile dysfunction and a lack of sexual desire also are associated with testosterone deficiency.

\section{Galactorrhoea in newborns:-}

Galactorrhoea sometimes occurs in newborns. High maternal estrogen levels cross the placenta into the baby's blood. This can cause enlargement of the baby's breast tissue, which may be associated with a milky nipple discharge.

In Ayurveda, galactorrhoea can be compared to a symptom manifesting due to Rasavaha sroto dusti. As Stanya is the upadhatu of rasa dhatu.[6] Normal function of stanya are breast development and maintenance of life.[7] Galactorrhoea is nothing but Stanyavriddhi. Feature of stanyavriddhi increased size of breast (stanya-pinatva), frequent flow of milk (muhur-muhur pravritti) and breast pain (toda).[8] Rasavahasrota get vitiated due to excessive intake of heavy (guru),cold(shita), unctuous(snighdha) food and over-worry.[9]

B. diffusa L.(Punarnava) occurs abundantly as a weed throughout India. It is a creeping and spreading perennial herb. It is an important medicinal plant much used in tradicinal medicine in many parts of the world. The plant dies during hot summers and puts forth fresh shoots after rains and is believed to be a rejuvenator. This plant was named in the honor of Hermann Boerhaan a famous 18 th century Dutch physician commonly known as tarvine. It is an herbal species of flowering plant in the four-o-clock family. Punarnama means which rejuvenates the body or renew the body. It is taken in herbal medicine and often used as a green vegetable in many parts of India.[10] The properties and action of punarnava are -

Rasa - Tikta, Kasaya, Modhur, Guna - Laghu, Ruksa, Veerya - Ushna, Vipak - Katu, Probhava - Not signify. Dosha-karma-Vata-kapha Shamak.[11] 
Worldwide Ethno medical uses of Punarnava are- In India B.diffussa has a long history of medicinal use in Ayurveda and Unani. Different plant parts used as an appetizer, eye tonic, flushing out the renal system, to treat seminal weakness and blood pressure. Its roots are used in treating Jaundice Ascites, Anasarca, scanty urine, internal inflammation, Asthma, Piles. The plain juice used as an antidote for rat poisoning. The seed are use as expectorant, carminative, muscular pain, lambago, scabis, scarpion sting, in Yunani medicine. Seed powder mixed with dried ginger, it is given in Urticaria. In Punjab, the drug is considered useful for eye.In Mumbai, it uses for dropsical swelling.In Goa, it uses as a diuretic in Gonarrhoea. In West Indies, use for gonarrhoea. In Arab country, it uses for the treatment of diabetes, stress, dyspepsia, inflammation, congestive heart failure, anti convulsant, anti fibrinolytic, night blindness, corneal ulcer etc. In Brazil the plant as a whole or, its extracts is used for albuminuria, Beri-beri ,bile insufficiency, cystitis, edema, gall stone, gonorrhea, guinea worms, hepatitis, Hypertension, Jaundice, Kidney disorders, Renal stone, Liver sclerosis, snake bite, spleenomegaly, urinary retention. In Guatemala, it is used for erysipelas, and guinea worms (Taylor, 2005). In Iran, it is used for abdominal pain, amaemia, ascites, asthma, blood purifier, cancer cararacts, child birth, cholera, constipation, cough, debility, digestive sluggishness, dropsy, dyspepsia, edema, eye problem, fever, heart ailments child birth hemorrhage, thoracic hemorrhage, internal parasites, lactation aid, menstrual disorder, rheumatism, as a diuretic, expectorant.In Iraq, it is used for edema, gonorrhea, liver, intestinal gas, joint pain, lumbago, nephritis, an appetite stimulant.In Nigeria, it is used for abscesses, asthma, boils, convulsions, epilepsy, fever, laxative, In West Africa it is used for abortion, guinea worms, and menstrual irregularities and as an aphrodisiac.In Tropical Africa the boiled roots are applied to ulcer abscess: The boiled leaves are considered expectorant and febrifuge and in large doses emetic. A decoction of aerial parts is also taken to treat gastro intestinal pains, intestinal worms and to regulate menstruation.In Mauritania, the seeds are ground and made into cakes which are coocked and eaten as a remedy for dysentery.[12]

Pharmacological Activities of B. diffusa L.(Punarnava) as per recent research are Diuretic ,Hepatoprotective , Cholerectic activity, Anti inflammatory activity, Haematinic Effect, $\quad \mathrm{Ca}^{+2}$ chennel antagonistic Effect, Corticosteroids like effect Emetic and cathartic Effect,Anti convulsant activity,Anti cancer activity,Anti Diabetic/Hypoglycaemic effect,Anti Amoebic , Anti Fibrinolytic activity, Anti fungal activity, Restorative activity against stress induced changes in adrenal cortisol level, Anti oxidant property (It produced 50\% inhibition of lipid peroxidation), Anti viral activity, Anti microbial activity specially Gram negative bacteria, Negative chronotrophic activity.etc[13]

\section{Details of the case:-}

A 19 year old female patient, reported to IPD of Raghunath Ayurved Mahavidyalaya and Hospital, Contai, West Bengal with complain of galactorrhoea of both breast predominantly left side, mild tenderness of both breast for last fifteen days. Associated complaints were dysmenorrhoea, general weakness, nausea and occasional vomiting, headaches. There was no history of serious systemic illness, any positive past and family history.

\section{History:-}

Mode of Onset:- Sudden.

Duration:- For fifteen days.

Precipitating Factors:- No such

Past History:- No such

Family History:- patient's mother suffer from psychological disturbance probably schizophrenia for last fifteen years and she is under treatment.

Drug History:- A detailed drug history is crucial; galactorrhoea is associated with a wide variety of drugs that raise serum prolactin levels. Frequent use of Domperidon for nausea and vomiting is positive here.

Gynecologic History:- Irregular menstrual cycle in 3to 5 days of duration. Patient is suffering from dysmenorrhoea, nausea, occasional vomiting during first day of menstruation. Her LMP was $12^{\text {th }}$ May, 2015.

Associated Symptoms:- Nausea, occasional vomiting, and headaches, loss of appetite, Constipation, cold intolerance, lethergy.etc

\section{Physical Examination:-}

General:- On examination patient is thin built, weight $45 \mathrm{~kg}$, non pallor, non icteric, no lymph gland enlarged and other vital signs are normal. Pulse rate $72 \mathrm{bpm}$ and blood pressure $110 \backslash 70 \mathrm{~mm}$ of $\mathrm{Hg}$. Visual field within normal limit.

Breast Examination:- No sign of local irritation, infection, or trauma in the both breast. 
Nipple Discharge:- A milky, thin, intermittent discharge from bilateral breasts, the discharge is scanty from right side and abundant from left one, on expressed and sometimes spontaneous. There was mild tenderness and no nodules.

\section{Laboratory Evaluation:-}

1. Pregnancy test-negative. (Dated on $31^{\text {th }}$ July, 2015).

2. Levels of serum prolactin( fasting) $-53.94 \mathrm{ng} \backslash \mathrm{ml}$ ( Dated on $4^{\text {th }}$ Aug,2015).

3. Level of serum T3-0.801ng $\backslash \mathrm{ml}$. T4-6.74mcg $\backslash 100 \mathrm{ml}$, TSH-4.41 microIU $\backslash \mathrm{ml}$. (Dated on $4^{\text {th }}$ Aug, 2015).

4. Levels of serum prolactin (fasting) $-0.48 \mathrm{ng} / \mathrm{ml}$ ( Dated on $5^{\text {th }}$ Nov, 2015).

5. CT of brain and pituitary-nothing abnormality detected. (Dated on $14^{\text {th }}$ Nov, 2015).

6. Levels of serum prolactin( fasting) $-0.377 \mathrm{ng} \backslash \mathrm{ml}$ ( Dated on $16^{\text {th }}$ Aug,2016).

\section{Materials and Methods:-}

1. Capsule Punarnava 2cap thrice daily (Himalaya Drug Company) for 3month.

2. Capsule Trikatu 2cap twice daily after meal (Himalaya Drug Company) for 30days.

Patient was advised to avoid day sleep, night awakening, guru and Kapha aggravating substance like heavy meal ,fast food, fatty food, curd,etc.. Breast stimulation by clothing, suckling, self-manipulation, or stimulation during sexual activity should be avoided.

\section{Observation:-}

The sign and symptoms observed like discharge and tenderness were subsiding after 10 days. Occasional scanty discharge was found on expressed. After 30 days discharge was completely absent.

\section{Discussion and Conclusion:-}

In Ayurveda, galactorrhoea can be compared to a symptom manifesting due to Rasavaha sroto dusti. As Stanya is the upadhatu of rasa dhatu. Normal function of stanya is breast development and maintenance of life. Galactorrhoea is nothing but Stanyavriddhi. Feature of stanyavriddhi increased size of breast (stanya-pinatva), frequent flow of milk (muhur-muhur pravritti) and breast pain (toda). Rasavahasrota get vitiated due to excessive intake of heavy (guru), cold (shita), unctuous(snighdha) food and over-worry(ati-cinta). Feature of Rasavahasroto dusti is similar to feature of Rasa dhatuvriddhi, that is feature of increased Kapha dosha .Kapha when increased produces poor digestion (Agni sadan), excess salivation (Proseka), laziness(alasya), feeling heaviness of the body(gourava), paleness(sveta) ,coldness(saita),feeling looseness of the body parts (slathangata) i.e, weakness ,dyspnoea (swas ), $\operatorname{cough}(k a s a)$, excess of sleep(ati nidra).These all features are very much similar with Hyperporlactenemia. On the other hand, Punarnava being a ushna virya and katu vipak dravya, it alleviate Kapha dosha as well as Vata dosha. Persons suffer from glactorrhoea must be avoid diet and regime which increases kapha dosha like heavy meal, curd, dairy product, day sleep etc and use fat free, little in quantity, warm meal possessing katu, tikta kashaya taste, honey, drugs which reduce fat, fasting, different kind of exercisese etc . Extensive study and research is necessary to find out the role of punarnava in hyperprolactenemia as well as others endocrinal disorder.

\section{Acknowledgement:-}

I acknowledge the patient, who gave me total history, allow me to examine private part, and for follow up. 


\section{References:-}

1. Jardines L. Management of nipple discharge. Am Surg. 1996; 62: 119-22.

2. John E Hall, Gyton and Hall Text book of pathology. Second south Asian Edision,Published by RELX Indian Private Limited, 2016,p-694.

3. Lee D-Y, Oh Y-K, Yoon B-K, Choi D. Prevalence of hyperprolactinemia in adolescents and young women with menstruation-related problems. Am J Obstet Gynecol. 2012. 206:213.e1-5.

4. Melmed S, Casanueva FF, Hoffman AR, et al. Diagnosis and treatment of hyperprolactinemia: an Endocrine Society clinical practice guideline. J Clin Endocrinol Metab. 2011 Feb. 96(2):273-88. [Medline].

5. Bope ET. Hyperprolactinemia. In: Conn's Current Therapy 2015. Philadelphia, Pa.: Saunders Elsevier; 2015. http://www.clinicalkey.com. Accessed Nov. 6, 2015.

6. Sharma Ram Karan and Dash Bhagawan, Carak Samhita, Cikitsa Sthan, 15 th chapter, verse-17, Chaukhambha Sanskrit Series Office, Varanasi, Reprint 2014, $4^{\text {th }}$ volume, p-14.

7. Sushurut samhita of Maharishi Sushurut, English commentary by Prof K.R. Srikantha Murthy, volume-1, Chaukhambha orientalia, Varanasi, reprint 2010, Sutra sthan, 15th chapter, shlok-5,p- 99.

8. Sushurut samhita of Maharishi Sushurut, English commentary by Prof K.R. Srikantha Murthy, volume-1, Chaukhambha orientalia, Varanasi, reprint 2010, Sutra sthan, 15th chapter, shlok-16,p- 103.

9. Sharma R.K and Dash Bhagawan, editors. Caraka Samhita. 7th edition Vol-2, Vimansthan5\13, Varanasi: Chaukhamba Sanskrit series office; 2015.p-178.

10. Sastri J.L.N, Drabya Guna Vijnana. Chaukhambha orientalia ,Varanasi, 3 rd Edition 2008,3 rd vol, p-437-441.

11. Mishra S,Bhavaprokash (Hindi), Chaukhambha Sanskrit Bhawan, Varanasi, 11 th Edition 2010, 1 st part, p426- 428.

12. Chopra, Ghosh and De, Indian Meditional Gazette.2002; 31:122-124,

13. Sharma P.C. et al, Data base on Medicinal Plants used in Ayurveda, Central council for Research in Ayurveda \& Siddha, New Delhi,2001 1 st Vol, p-264. 